\title{
PHENOTYPIC AND ANTIGENIC VARIATION OF MYCOPLASMA GALLISEPTICUM VACCINE STRAINS
}

\author{
Priscila N. Ferraz; Maria das Graças M. Danelli*
}

Departamento de Microbiologia e Imunologia Veterinária, Instituto de Veterinária, Universidade Federal Rural do Rio de Janeiro, Seropédica, RJ, Brasil.

Received: June 18, 2002; Returned to Authors: November 04, 2002; Approved: September 08, 2003

\begin{abstract}
Phenotypic and antigenic variations among Mycoplasma gallisepticum vaccine $\mathrm{F}$ and Ts-11 strains were investigated by SDS-PAGE and serological methods (hemagglutination-inhibition and immunoblot assays). The SDS-PAGE system followed by densitometer analysis showed weak phenotypic variability between the strains, being the major difference close to the $75 \mathrm{kDa}$ level where a prominent peptide band was detected only in the $\mathrm{F}$ vaccine strain. Polyclonal antibodies to the $M$. gallisepticum antigens produced in chickens were used in serological tests for this antigenic variability study. There were strong cross-reactions between the strains and homologous/ heterologous antibodies. The most evident characteristic was the specific response of the vaccine-type F polyclonal antiserum to the $75 \mathrm{kDa}$ peptide band of the homologous strain.
\end{abstract}

Key words: Mycoplasma gallisepticum, phenotypic variation, antigenic variation.

\section{INTRODUCTION}

Mycoplasmosis continue to be the major problem in poultry, being Mycoplasma gallisepticum (MG) infections responsible for important economic losses (24). To reduce this problem, layer producers commonly have used MG live vaccines in attempt to immunize and protect chicken flocks (2). The MG-F strain is the most used as vaccine to prevent the colonization by the most virulent MG strains. The continuous vaccination may displace field strains from multiple-age poultry production sites (1). However, MG-F is pathogenic for turkeys (13), and has been associated with MG outbreaks in meat and breeder turkeys under field conditions (12).

Attenuated MG Ts-11 strain has been produced commercially as live vaccine. The strain was selected after exposure passage of an immunogenic Australian field isolate (strain 80083) of MG to $\mathrm{N}$-methyl-nitro-N-nitrosoguanidine (22). This strain was found to be poorly transmitted from vaccinated to unvaccinated birds and showed little or no virulence for chickens and turkeys (21). This suggests that it could be safer than the MG-F strain for vaccinated flocks. The ability to replace wild or vaccine MG strain has originated controversy among researchers $(11,23)$.
For use of new MG vaccines knowledge about the variability of these vaccine strains is essential. Phenotypic, antigenic and genotypic heterogeneity among MG strains have been studied by sodium dodecyl sulfate-polyacrylamide gel analysis (6), hemagglutination-inhibition test (8), DNADNA hybridization (7), polymerase chain reaction/PCR $(15,16)$, restriction endonuclease DNA analysis (10), flow cytometry (1), southern blot analysis, using a ribosomal RNA gene probe (25), and immunoenzymatic assays (17). These techniques have made it feasible to determine if MG-F strain long-term used as a vaccine in multiple-age commercial layers has resulted in displacement of the original field strain with the $\mathrm{F}$ vaccine strain. Random amplified polymorphic DNA analysis was used to discriminate between F and TS-11 strain (3), but one of the disadvantages of current available vaccines is that there is no convenient serological technique to accurately distinguish between vaccinated or naturally infected flocks (23). A MG marker to distinguish vaccine from wild type-strains would be useful as diagnostic tool. MG-F strain has a unique molecular band, a $75 \mathrm{kDa}$ protein, which can be used as a marker to differentiate it from the other MG strains by immunoblot (18).

*Corresponding author. Mailing address: Instituto de Veterinária, Universidade Federal Rural do Rio de Janeiro, BR 465, Km 07. 23890-000, Seropédica, RJ, Brasil. E-mail: danelli@ufrrj.br 
The objective of this study was to search for Ts-11 molecular marker that could be used to distinguish it from MG-F and wild strains.

\section{MATERIALS AND METHODS}

\section{Microorganisms}

MG strains received for study were characterized by PCR $(15,16)$. MG-S6 strain was recovered from a chicken experimentally infected with S6 virulent strain. Originally isolated and maintained by Dr. R. Yamamoto (University of California, USA), this strain was given to Dr. Elmiro R. do Nascimento. (UFF, Niteroi, RJ), and used as positive control. MG-F is a low virulent strain used as vaccine in Brazil marketed by Coopers ${ }^{\circledR}$ as MG-F vaccine. MG Ts-11, attenuated strain used as vaccine in Brazil, marketable by Rhodia-Merieux ${ }^{\circledR}$ as Mycovax Ts-11 vaccine.

\section{Cellular antigen preparation}

MG-S6 strain was stored (v/v) in glycerol, MG-F a lyophilized vaccine, was maintained at $4^{\circ} \mathrm{C}$ and the MG Ts- 11 vaccine was maintained at $-20^{\circ} \mathrm{C}$. All strains were cultivated in Hayflick modified medium (5) with $10 \%$ equine serum. The cultures were incubated at $37^{\circ} \mathrm{C}$ and the cells were harvested by centrifugation at the begining of the acidification of the medium. Protein concentration from each cellular suspension was determined as described by Lowry et al. (14).

\section{Polyclonal chicken antisera (PCA) preparation}

Three to four years old pathogen free chickens (Gallus gallus), were used for PCA preparation. The birds were immunized through intramuscular inoculation with $1000 \mu \mathrm{g}$ of cellular antigen, mixed (v/v) with Freundt Complete Adjuvant. The specific antibodies were titred by hemagglutination inhibition (HI) test. PCA was obtained 30 days after inoculation, and stored at $-20^{\circ} \mathrm{C}$.

\section{SDS-Page}

The mycoplasmal proteins were submitted to SDS-PAGE electrophoresis with $10 \%(\mathrm{w} / \mathrm{v})$ of acrylamide/bis $37.5 \%$ gels and stained with Coomassie Brilliant Blue R-250 (4). The protein band profile was analysed by densitometry.

\section{Western blot}

The electrophoresed proteins were transferred from gels to $0.22 \mathrm{~mm}$ nitrocellulose sheets (NS), as cited by Tsang et al. (20). The electrotransference was conducted for $1 \mathrm{~h}$ at $100 \mathrm{~V}$ (19). The NS were stained with Ponceau $S$ to observe the peptide bands of 75 and $64 \mathrm{kDa}$. The NS were washed with distilled water and stored at $-20^{\circ} \mathrm{C}$.

\section{Immunoblot}

The NS were incubated with PCA diluted 1/100 in PBS pH 7.2/0.3\% Tween 20 (PBST) and blocked with 5\% skim milk. The
NS were washed with PBST four times for 3 min each one. The second peroxidase-labeled antibody (BioManguinhos, FIOCRUZ, Brazil), diluted 1/500 in PBST, was added and the mixture was incubated for $1 \mathrm{~h}$. Then, the NS were submitted to additional washing with PBST for 5 min. Freshly prepared developing solution ( $60 \mathrm{mg}$ de DAB, $100 \mu \mathrm{L}$ de $\mathrm{H}_{2} \mathrm{O}_{2} 30 \%$ in $100 \mathrm{~mL}$ of Tris $0.15 \mathrm{M} \mathrm{pH} \mathrm{7.6)} \mathrm{was} \mathrm{then} \mathrm{added.} \mathrm{The} \mathrm{reaction}$ was neutralized with distilled water and the NS sheets were air dried. All steps were carried out at room temperature.

\section{Hemagglutination-inhibition (HI) test}

$\mathrm{HI}$ assays to detect $\mathrm{MG}$ antibodies were performed on PCA samples using four-hemaggluination units of antigen obtained from MG-S6 (9). Positive and negative MG stand-sera were used as controls.

\section{RESULTS}

\section{Phenotypic analysis}

The results for the MG strains are summarized in Fig. 1 and 2. MG strains presented differences on protein banding patterns. However, the patterns were similar, mainly those below $66 \mathrm{kDa}$ level. The peptide band of $64 \mathrm{kDa}$, characteristic of MG species, was observed in all strains. MG Ts-11 strain presented minor but distinct variation at this peptide band level, particularly by

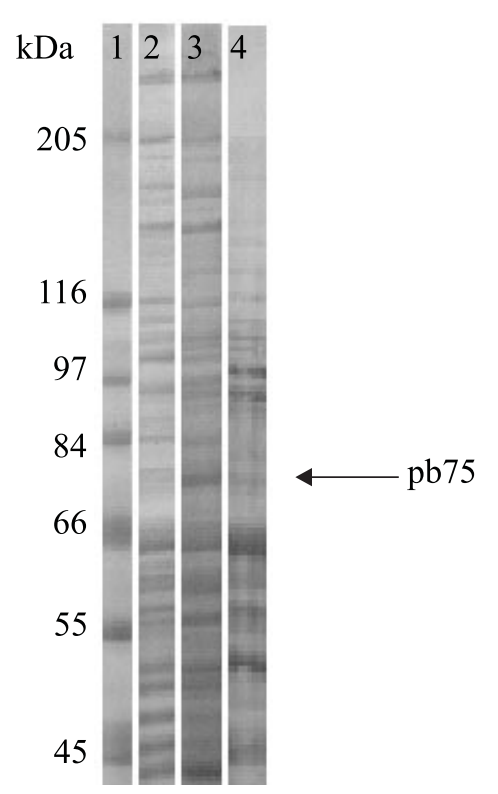

Figure 1. SDS-PAGE of proteins from Mycoplasma gallisepticum strains. Lane 1, molecular mass standards (Sigma); Lane 2, MG Ts-11/Mycovax Ts-11 vaccine, Rhodia-Merieux ${ }^{\circledR}$; Lane 3, MG-F/ MG-F vaccine, Coopers ${ }^{\circledR ;}$; Lane 4, MG-S6(208) / virulent strain. The $75 \mathrm{kDa}$ peptide band is marked in the figure as peptide band (pb) 75 and indicate by an arrow. 

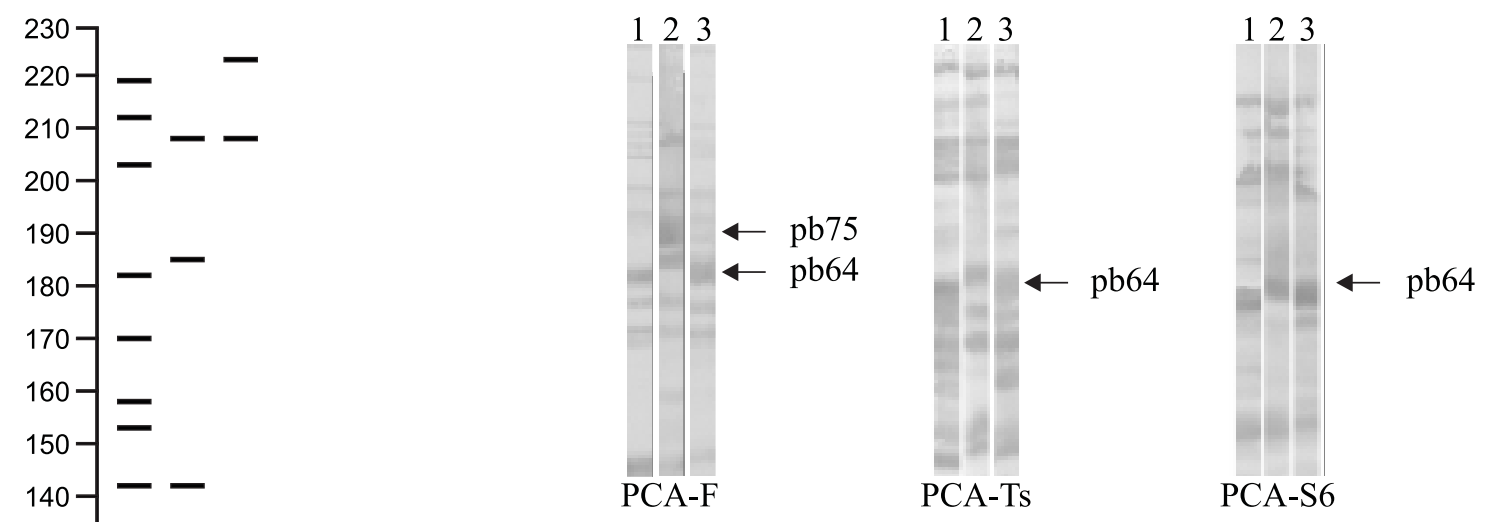

Figure 3. Immunoblots from three Mycoplasma gallisepticum strains. Lane 1, MG Ts-11; lane 2, MG-F and lane 3, MG-S6, reacted respectively with chicken sera PCA-Ts, PCA-F and PCA-S6. The 75 and $64 \mathrm{kDa}$ immunoreactive locus are indicated as pb 64 and pb 75, respectively and are marked by an arrow.

The wide and specific response of PCA F serum to the peptide band $(75 \mathrm{kDa})$ of its homologous strain was the unique characteristic in immunoblot test.

\section{DISCUSSION}

This study showed that the protein SDS-PAGE gel profiles of vaccine and wild type MG strains were similar. A $64 \mathrm{kDa}$ peptide band was already observed in all strains of $M$. gallisepticum $(12,17)$. In this study, we describe that the major difference among the strains tested was the detection of a $75 \mathrm{kDa}$ band exclusively in MG-F but not in MG S6, or weakly detected on MG Ts-11. These results confirm the previously reported phenotypic diversity between F and S6 MG strains $(6,10,17)$.

Although a darkly stained $75 \mathrm{kDa}$ band was observed in the densitomer analysis, which showed a distinct band at the 63 kDa level.

Phenotypic variation among vaccine strains were better detected by densitometer scanning above $75 \mathrm{kDa}$ level where the bands in MG Ts-11 strain were very weak or did not match above this level in F strain. On the other hand, a prominent peptide band of $75 \mathrm{kDa}$ in MG-F strain was observed in the gel. The MG Ts-11 strain showed a large band around the $75 \mathrm{kDa}$ level, weakly stained by Coomassie Brilliant Blue. The densitometer analysis indicated where the peptide banding at this level in MG Ts-11 strain had minor band percentage than observed in MG-F strain, $1.68 \%$ and $4.08 \%$, respectively (data not shown).

\section{Antigenic analysis}

Antigenic differences among vaccine and wild MG strain were studied by $\mathrm{HI}$ and Immunoblot assays. Using MG-S6 strain as antigen all PCA showed titres of 80 in HI test. By immunoblot test, PCA reactivity pattern did not vary much and occurrence of high cross-reactivity among the sera was observed (Fig. 3). was present only in some MG-F seeds (6). This variation among MG-F seeds may constitute a problem for the use of this peptide band as a vaccine molecular marker. The MG-F seed (MG-F vaccine, Coopers), used as vaccine in Brazil, shows this peptide band, which may be useful for monitoring the prevalence of the MG wild type in places where such vaccine is used. The MG Ts11 vaccine strain (Mycovax Ts-11/ Rhodia-Merieux) also showed a similar protein pattern when compared to the $\mathrm{F}$ vaccine strain. However, this strain did not present the $75 \mathrm{kDa}$ peptide band.

When chicken antibody response to the MG strains was evaluated by hemagglutination and immunoblot assays, no antigenic variability was detected when comparing the vaccine and wild type strains. Previous report has showed that the HI assay is not suitable to distinguish variability among strains responsible for infection and serum conversion (17). Similary, using the immunoblot test, we observed that the PCA reactivity pattern showed a high cross-reaction among the sera. 
Rabbit policlonal antibodies for MG-F, K810, S6 and A5969 strains were previously produced by Thomas and Sharp (17). These antibodies recognized most peptide bands from heterologous strains. Since heterologous and homologous antibodies to MG-S6 and MG-F recognized both pb63 (MG Ts11) and pb64 (MG-S6 and MG-F), the peptide band profile may be similar. Therefore, differences detected in protein profile may reflect differences on peptide molecular weight.

Eventhough the Ts- 11 strain showed a faint $75 \mathrm{kDa}$ band when stained with Coomassie blue, this band was not detected when gels were blotted with anti-Ts-11 or anti F sera. However the antiF serum clearly detected a $75 \mathrm{kDa}$ band in the MG-F strain. These data suggest that the MG-F vaccine strain is the only isolate that shows a molecular marker that can differentiate it from the wild MG strain. No specific molecular marker was detected in the Ts-11 strain.

\section{RESUMO}

\section{Variabilidade fenotípica e antigênica de cepas variáveis de Mycoplasma gallisepticum}

Cepas vacinais de Mycoplasma gallisepticum, Fe TS-11, foram examinadas quanto às suas variações fenotípicas e antigênicas, por SDS-PAGE e através de dois métodos sorológicos (inibição da hemaglutinação e imunoeletroforese). A análise densitométrica das bandas obtidas nos géis de poliacrilamida mostrou pequena variabilidade fenotípica entre as amostras, sendo a banda peptidica de $75 \mathrm{kDa}$ detectada apenas na amostra vacinal F. Anticorpos policlonais produzidos em galinha foram utilizados nos ensaios sorológicos para estudar a variabilidade antigênica das amostras. Houve elevada reatividade cruzada entre as amostras e os anticorpos homólogos e heterólogos. A característica mais evidente foi a resposta específica da banda peptídica de $75 \mathrm{kDa}$ da vacina $\mathrm{F}$ ao anticorpo homólogo.

Palavras-chave: Mycoplasma gallisepticum, variação fenotípica, variação antigênica.

\section{REFERENCES}

1. Brown, J.E.; Branton, S.L.; May, J.D. Epitope diversity of F strain Mycoplasma gallisepticum detected by Flow Cytometry. Avian Dis., 41:289-295, 1997

2. Carpenter, T.E.; Mallinson, E.T.; Miller, K.F.; Gentry, R.F.; Schwartz, L.D. Vaccination with F-strain Mycoplasma gallisepticum to reduce production losses in layer chickens. Avian Dis., 25:404-409, 1981.

3. Fan, H.H.; Kleven, S.H.; Jackwood, M.W. Application of polymerase chain reaction with arbitrary primes to strain identification of Mycoplasma gallisepticum. Avian Dis., 39:729-735, 1995.

4. Ferraz, P.N.; Danelli, M.G.M.; Nascimento, E.R.; Menezes, C.C.P.; Lizeu, J.O.P. Protein Profile Analyses by SDS-PAGE of Mycoplasma gallisepticum strains S6(208) and F-K810 Cultured in Hayflick's and Frey's Media. Braz. J. Microbiol., 31:113-115, 2000.

5. Freundt, E.A. Culture media for classic mycoplasmas. In: Razin, S.; Tully, J.G. (eds.) Methods in Mycoplasmology. Academic press., New York, 1983, 1:127-135.
6. Khan, M.I.; Lam, K.M.; Yamamoto, R. Mycoplasma gallisepticum strain variations detected by sodium dodecyl sulfate-polyacrylamide gel electrophoresis. Avian Dis., 31:315-320, 1987.

7. Kleven, S.H.; Browning, G.F.; Bulach, D.M.; Ghiocas, E.; Morrow, C.J.; Whithear, K.G. Examination of Mycoplasma gallisepticum strains using restriction endonuclease DNA analysis and DNA-DNA hybridization. Avian Pathol., 17:559-570, 1988

8. Kleven, S.H.; Morrow, C.J.; Whithear, K.G. Comparison of Mycoplasma gallisepticum strains by hemagglutination-inhibition and restriction endonuclease analysis. Avian Dis., 32:731-741, 1988.

9. Kleven, S.H.; Yoder Jr, H.W. Mycoplasmosis. In: Perchase, H.G.; Arp, L.H.; Domermuth, C.H.; Pearson, J.E. (eds). A laboratory manual for the isolation and identification of avian pathogens. American Association of Avian Pathologists, Dennett Square, 1989, p.55-62.

10. Kleven, S.H.; Khan, M.I.; Yamamoto, R. Fingerprinting of Mycoplasma gallisepticum strains isolated from multiple-age layers vaccinated with live F strain. Avian Dis., 34:984-990, 1990.

11. Kleven, S.H.; Fan, H.H.; Turner, K.S. Pen trial studies on the use of live vaccines to displace virulent Mycoplasma gallisepticum in chickens. Avian Dis., 42:300-306, 1998.

12. Ley, D.H.; Avakian, A.P.; Berkhoff, F. Clinical Mycoplasma gallisepticum infection in multiplier breeder and meat turkey detected by sodium dodecyl sulfate-polyacrylamide gel electrophoresis, restriction endonuclease analysis, and polymerase chain reaction. Avian Dis., 37:854-862, 1993.

13. Lin, M.Y.; Kleven, S.H. Cross-immunity and antigenic relationships among five strain of Mycoplasma gallisepticum in young Leghorn chickens. Avian Dis., 26:496-507, 1982.

14. Lowry, O.H.; Rosebrough, J.N.; Farr, A.L.; Randall, R.L. Protein measurement with the folin phenol reagent. J. Biol. Chem., 193:265275, 1951

15. Nascimento, E.R.; Yamamoto, R.; Herrick, K.R.; Tait R.C. Polymerase chain reaction for detection of Mycoplasma gallisepticum. Avian Dis., 35:62-69, 1991.

16. Nascimento, E.R.; Yamamoto, R.; Khan, M.I. Mycoplasma gallisepticum F-vaccine strain-specific polymerase chain reaction. Avian Dis., 37:203-211, 1993.

17. Thomas,C.B.; Sharp, P. Detection of Antigenic Variation among strain of Mycoplasma gallisepticum by Enzyme-Linked Immunosorbent Inhibition Assay (ELISA) and Western Blot Analysis. Avian Dis., 32:748-756, 1988.

18. Thomas, C.B.; Sharp, P.; Fritz, B.A.; Yuill, T.M. Identification of F strain Mycoplasma gallisepticum isolates by detection of na immunoreactive protein. Avian Dis., 35:601-605, 1991.

19. Towbin, H.; Staehelin, T.; Gordon, J. Electrophoretic transfer of proteins from polyacrylamide gels to nitrocellulose sheets: procedure and some applications. Proc. Nalt. Acd. Sci., 76:4350-4354, 1979.

20. Tsang, V.C.W.; Peralta, J.M.; Simons, R.A. The enzyme-linked immuno-electrotransfer blot techniques (EITB) for studying the specificities of antigens and antibodies separated by gel electrophoresis. Meth. Enzymol., 92:377-391, 1983.

21. Whithear, K.G.; Ghiocas, E.; Markham, P.F.; Marks, D. Examination of Mycoplasma gallisepticum isolates from chickens with respiratory disease in commercial flock vaccinated with a living M. gallisepticum vaccine. Aust. Vet. J., 67:168-174, 1990.

22. Whithear, K.G.; Soeripto, G.; Harringan, K.E.; Ghiocas, E. Safety of temperature sensitive mutant Mycoplasma gallisepticum vaccine. Aust. Vet. J., 67:159-165, 1990.

23. Whithear, K.G. Control of avian mycoplasmosis by vaccination. Rev. Sci. Tech. Off. Int. Epiz., 15:1527-1553, 1996.

24. Yoder Jr, H.W. Mycoplasma gallisepticum infection. In: Calnek, B.N. (ed.). Disease of Poultry. Iowa State University Press, 1991, p.198-212.

25. Yogev, D.; Levisohm, S.; Kleven, S.H. Halachmi, D.; Razin, S. Ribosomal RNA gene probes to detect intraspecies heterogeneity in Mycoplasma gallisepticum and M. synoviae. Avian Dis., 32:220231, 1998. 